\title{
MECHANICAL PROPERTIES OF THE PACKAGE OF FERROMAGNETIC SHEETS
}

\author{
WIESŁAW KRZYMIEŃ \\ Materials and Structure Research Centre, Institute of Aviation, \\ Al. Krakowska 110/114, 02-256 Warsaw, Poland \\ wieslaw.krzymien@ilot.edu.pl
}

\begin{abstract}
The paper presents the measurement method and results as well as the results of comparative calculations aimed at determination of material data for the package of ferromagnetic sheets insulated with epoxy lacquer. During the test, the package of sheets was treated as a 3D orthotropic material. The values of Young's and Kirchhoff's moduli for a pre-compressed package of sheets, in accordance with the used manufacturing technology of the medium and high power electric motors' rotors, were determined. The carried out FEM comparative calculations confirmed that the determined mechanical parameters of the package of sheets as a 3D orthotropic material, i.e. Young's and Kirchhoff's moduli, for the compressive stress range of $1.0 \div 2.5 \mathrm{MPa}$, are included in the linear range. It was assumed that the determined mechanical properties of the package of sheets are necessary at the design stage for FEM simulation calculations of the electric motors' vibration and strength properties. As a result of the tests, it was found that they should be repeated in order to determine the properties of other sheets or those coated with different insulating lacquer.

Keywords: asynchronous motor, package of sheets, FEM, vibration.
\end{abstract}

\section{INTRODUCTION}

The rotor of electric squirrel cage motors is constructed of a package of ferromagnetic sheets insulated with lacquer. The analysis of the motor's vibration properties also includes appropriate simulation calculations of the rotor, which usually use a finite element method (FEM). The construction of the motor, the rotor of which operates in the supercritical range (rotor's revolutions are greater than the rotor shaft bending frequency), requires the calculations including orthotropic properties of a package of the rotor's sheets.

During the tests, the data provided by the manufacturer [1] was used, however, it does not contain all the data needed for calculations.

The publication includes the FEM calculation results of squirrel cage induction motors' rotors and stators, however, as it results from the work content (e.g. $[2,3])$, the actual data with mechanical properties of the package of sheets was not used for calculations. In the calculations, this part of the rotor was treated as being made of an isotropic material or as it was in [4], these properties were only estimated as orthotropic. 
This paper presents the method of carried out research, measurement results and comparative calculation results aimed at checking the material data values for the package of sheets, which make it possible to perform FEM calculations related to the rotor's vibration of the squirrel cage motor. Determination of mechanical properties of the package of sheets used for manufacturing the electric motors' rotors included:

1. determination of sheet and lacquer thickness,

2. measurement of Young's $E$ and Kirchhoff's $G$ moduli,

3. performance of verification calculations.

The measurements were carried out for one type of sheets used in the construction of rotors of the selected motors' models.

\section{SHEET AND LACQUER THICKNESS MEASUREMENT}

On the basis of data provided by the manufacturer, the applied ferromagnetic sheet has the nominal thickness of $0.5 \mathrm{~mm}$, and it is coated on both sides with lacquer electrically insulating sheets between each other in the package.

The measurement of the lacquer layer thickness was performed with the use of an electron microscope at approx. x 10000 magnification of the image in several places of the grounded edge of the sheet samples (Fig. 1) [5].

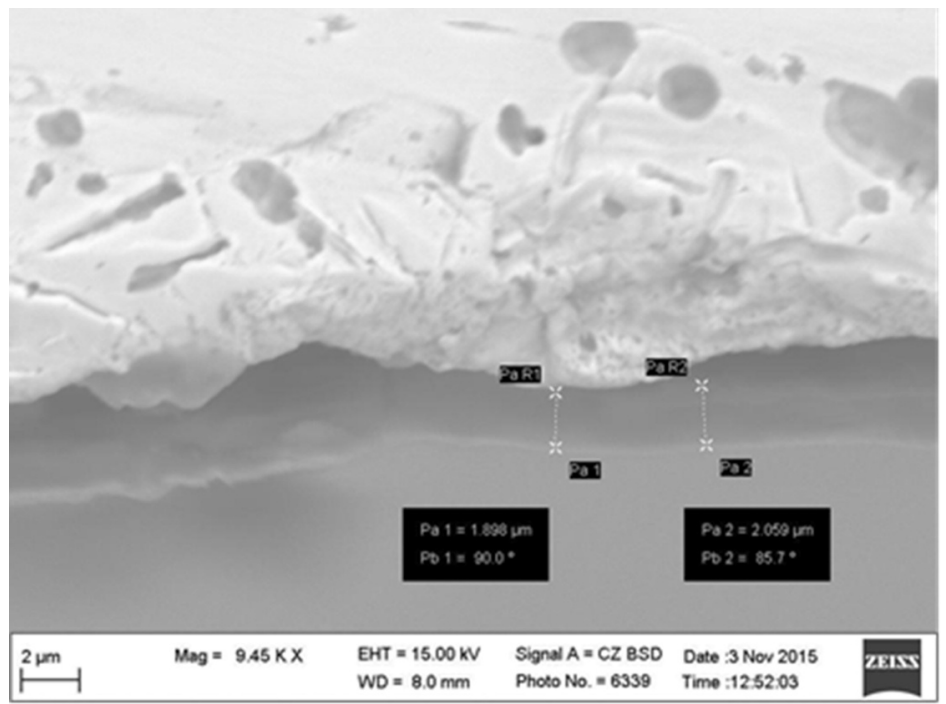

Fig. 1. Lacquer layer and outer part of the sheet visible under the electron microscope [5]

The sample image showed the sheet surface porosity typical of a rolled surface. The lacquer thickness was uneven and amounted between $0.001 \div 0.002 \mathrm{~mm}$. The thickness measurement of the sheet in the package was performed by measuring the height of the package of 100 pieces of the same sheet discs under low pressure (approx. $1 \mathrm{~N} / \mathrm{cm}^{2}$ ). The package measurement was performed with the use of a calliper in 3 places, obtaining the following result: $51.58 \pm 0.03 \mathrm{~mm}$, thus the average thickness of one sheet in the package is $0.5158 \mathrm{~mm}$. The difference in the sheet thickness means that, on average, there is a gap of less than $0.01 \mathrm{~mm}$ between two successive sheets in the package. The gap may arise due to: deformation of the edge cut on the press of the sheet forms, irregularity of individual sheets or dust. 
After the test described below, the height of the package of 100 discs of the tested sheet was checked again: the dimension was unchanged, which indicates spring deflection of sheets during the test.

\section{MEASUREMENT OF YOUNG'S AND KIRCHHOFF'S MODULI}

According to the manufacturer's data [1], the applied sheet has the following typical strength data in the direction of rolling:

1. Young's modulus

2. yield strength $(0.2 \%)$

$E_{x \boldsymbol{x}}=200000 \mathrm{MPa}$,

3. strength limit

$R_{\boldsymbol{e}}=325 \mathrm{MPa}$,

$R_{m}=465 \mathrm{MPa}$.

In the transverse direction to the direction of rolling, the above strength data is approx. $5 \%$ greater, including:

Young's modulus

$E_{y y}=210000 \mathrm{MPa}$.

In addition, in case of the sheet, the following was adopted:

1. Kirchhoff's modulus

$G_{x y} \approx 80 \mathrm{GPa}$,

2. Poisson's ratio

$v \approx 0.3$.

Young's modulus in a direction perpendicular to the plane of sheets, $E_{z z}$ was determined on the basis of the compression characteristics of the package of sheets. For this purpose, the measurement of deflection of the package of sheets under the influence of compressive force was performed.

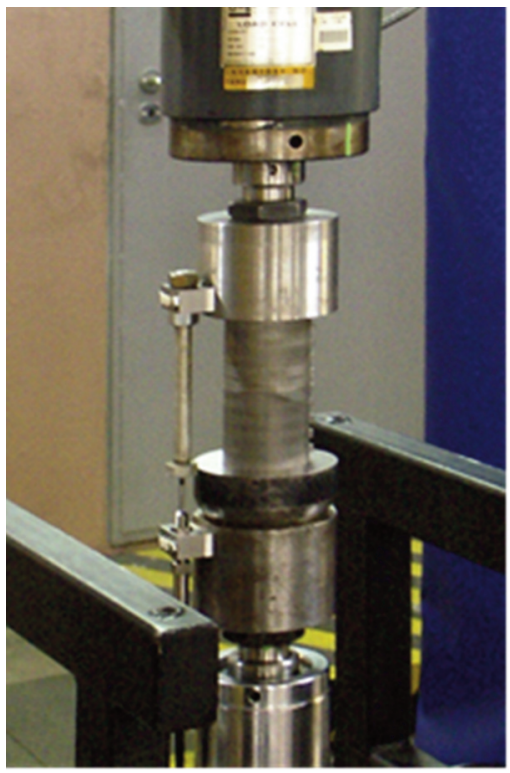

Fig. 2. Package of sheets during

compression testing in the testing machine

[Author, 2015]

Figure 2 shows the package of sheets with the height of approx. $103 \mathrm{~mm}$ consisting of 200 sheet discs with the diameter of $60.0 \mathrm{~mm}$. The package is located between a force measuring head and a selfadjusting head (they level possible uneven distribution of compressive force resulting from different thickness of sheets). On the left side of the package, an inductive displacement sensor is visible. 
Figure 3 shows the results of five series of deflection measurements of the package of sheets. The measurements were performed one by one recording of deflection in the compressive force function in order to check the measurement repeatability and the elastic hysteresis of the package of sheets. The repeated measurement of deflection in the compressive force function was also aimed at checking the package of sheets and achieving data in order to determine the average values. As it results from the graphs, the deflection hysteresis of the package of sheets slightly decreases, but the average rigidity for given pressure force remains constant.

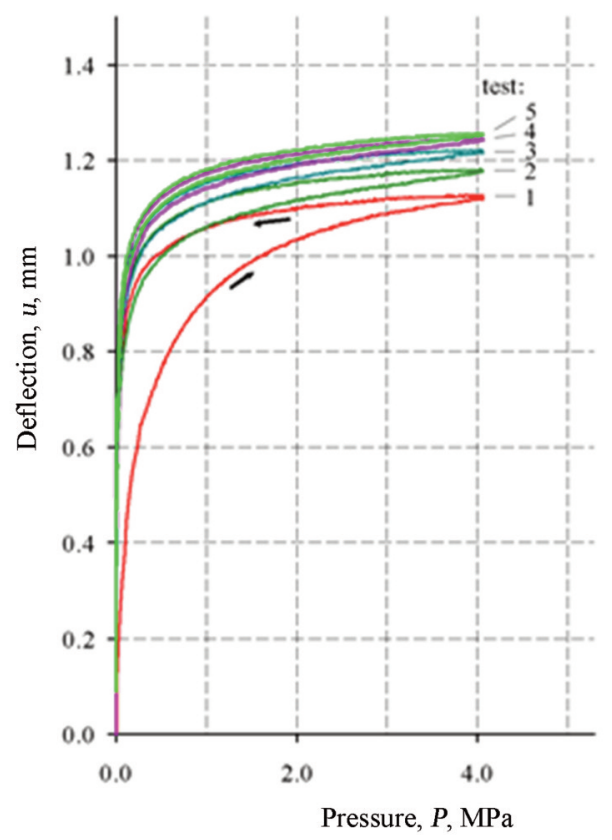

Fig. 3. Characteristics of the compressed package of sheets: in the pressure force function for 5 successive tests [Author, 2015]

Young's $E$ modulus in a direction perpendicular to the plane of sheets was determined in accordance with the following formula:

$$
E=\Delta p * \frac{l}{\Delta u}
$$

where: $\Delta p$-pressure increase, $\Delta u$-deflection of the package of sheets under the influence of the pressure increase, $l$ - package height.

The rotor manufacturing technology includes folding the package of sheets on the motor shaft, and then the pre-compression of the package (along the shaft axis) with the amount corresponding to the pressure of $1.3 \div 1.6 \mathrm{MPa}$ (not more than $2 \mathrm{MPa}$ ) is introduced, and then it is blocked by screwing with long bolts or welding the rods (inserting through holes in the package in parallel to the shaft axis). Therefore, the measurements for the compressive force corresponding to the pressure of $0 \div 4 \mathrm{MPa}$ were performed. 


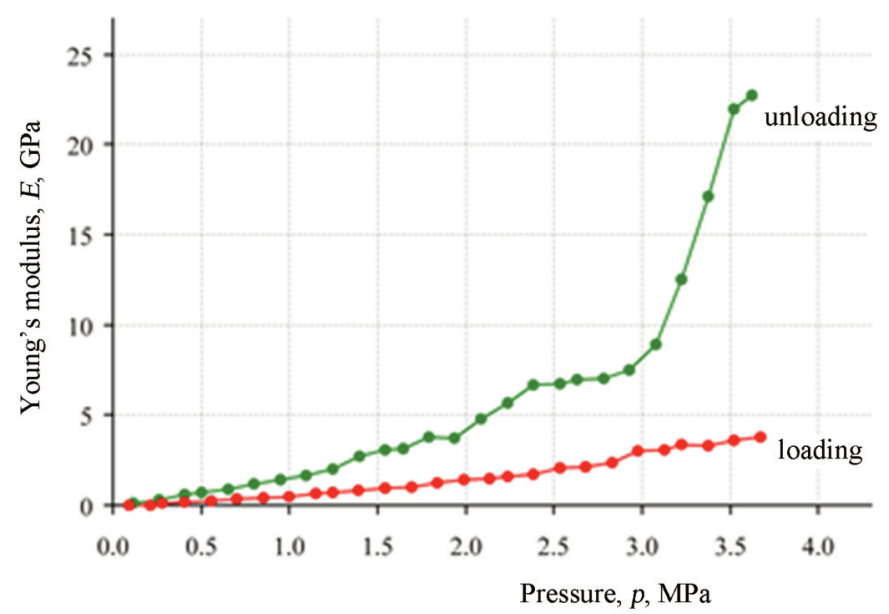

Fig. 4. Relationship of Young's modulus on the pressure level of the compressed package of sheets for the first compression test [Author, 2015]

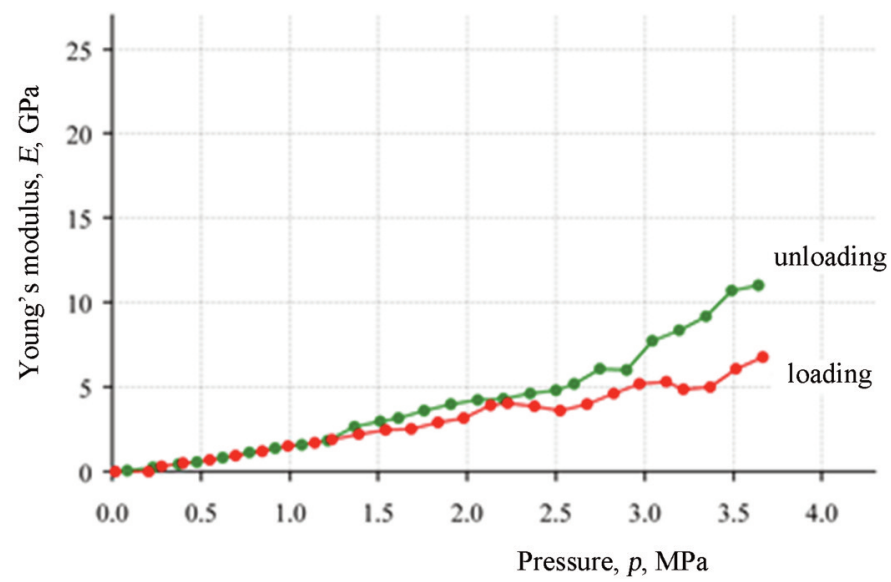

Fig. 5. Relationship of Young's modulus on the pressure level of the compressed package of sheets for the fifth compression test [Author, 2015]

The calculated sizes of $E_{z z}$ modulus for the adopted range of compressing the package was listed in Table 1.

Tab. 1. List of determined sizes of Young's modulus for the adopted compression force of the package of sheets

\begin{tabular}{|c|c|c|c|c|c|c|}
\hline \multirow{3}{*}{ Pressure } & \multicolumn{6}{|c|}{ Young's modulus, $E_{z z}$} \\
\hline & \multicolumn{2}{|c|}{ 1. test } & \multicolumn{2}{|c|}{ 5. test } & \multicolumn{2}{|c|}{ average values } \\
\hline & loading & unloading & loading & unloading & loading & unloading \\
\hline $\mathrm{MPa}$ & $\mathrm{GPa}$ & $\mathrm{GPa}$ & $\mathrm{GPa}$ & $\mathrm{GPa}$ & $\mathrm{GPa}$ & $\mathrm{GPa}$ \\
\hline 1.3 & 0.8 & 2.3 & 2,2 & 2.6 & 1.50 & 2.45 \\
\hline 1.6 & 1.0 & 3.1 & 2.5 & 3.1 & 1.75 & 3.10 \\
\hline
\end{tabular}


For FEM calculation of the rotor of $E_{z z}$ size, the average values were adopted:

1. at the pressure of approx. $1.3 \mathrm{MPa}: E_{z z}=2.0 \mathrm{GPa}$,

2. at the pressure of approx. $1.6 \mathrm{MPa}: E_{z z}=2.4 \mathrm{GPa}$.

Due to the lack of changes in the cross-section dimensions of the compressed package, as Poisson's ratio in Z direction, it should be adopted as follows: $v=0$.

Measurement of Kirchhoff's $G_{\boldsymbol{x}}$ and $G_{\boldsymbol{y}}$ moduli was performed for the same package of sheets.

Figure 6 presents the package of sheets, to the inside of which an additional sheet with a lug (made of the same material) was inserted. By pulling the sheet, the shear force - was applied in the plane of sheets. The force was introduced with the cord and measured with the electronic dynamometer.

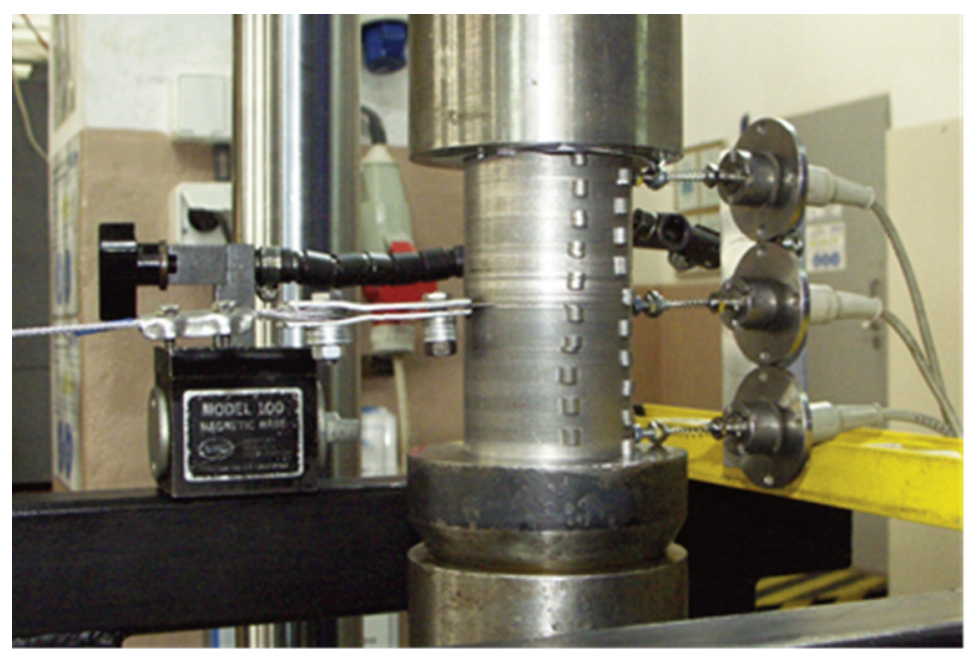

Fig. 6. Test of shearing the package of sheets [Author, 2015]

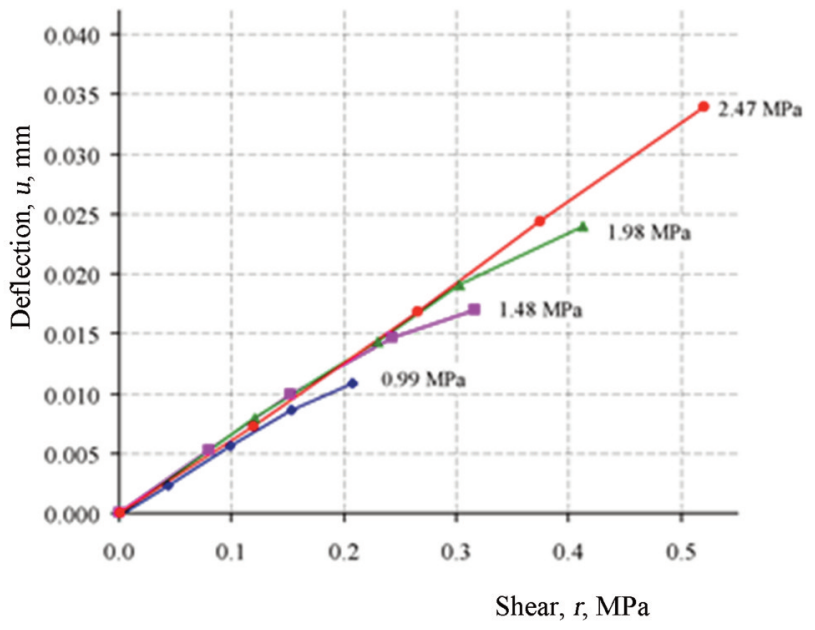

Fig. 7. Characteristics of deflection the package of sheets in the shear stress function for four stress magnitudes of the compression of sheets [Author, 2015] 
During the test, the displacement of the central sheet relative to end sheets was measured. The measurements were performed with three displacement sensors. The height of the measured part of the package (distance between the upper and lower sensors) was $95 \mathrm{~mm}$. The measurement results were presented in Figure 7. The measurements were carried out for four compression force magnitudes of the package of sheets and for four shear force magnitudes. The maximum shear force accounted for approx. $10 \%$ of pressure force.

In the tested range, the package rigidity is very similar and close to linear properties: the deflection hysteresis between loading and unloading was at the level of the measurement error, i.e. $0.001 \mathrm{~mm}$. For each compression force, Kirchhoff's $G$ modulus was determined according the following formula:

$G=\tau * \frac{l}{\Delta u}$

where: $\tau$ - shear stress as the shear force per unit of the package cross-sectional area, 1 - package height, $\Delta u$ - transverse deflection of the package of sheets.

The relationship of Kirchhoff's modulus size on pressure on the package of sheets is presented by the graph in Figure 8.

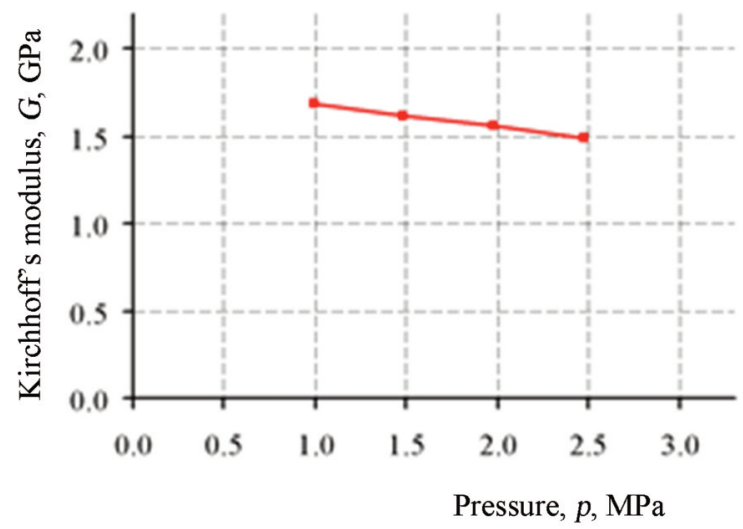

Fig. 8. Relationship of measured Kirchhoff's modulus on pressure on the package of sheets [Author, 2015]

Kirchhoff's modulus, determined with the use of this method, for the compressed package of sheets in the pressure range of $1.3 \div 1.6 \mathrm{MPa}$ on average amounts to $G_{\boldsymbol{x}}=G_{\boldsymbol{y}}=1.6 \mathrm{GPa}$.

\section{VERIFICATION CALCULATIONS}

In order to check and verify the obtained data, FEM calculations were performed for the carried out tests. A model of the package of sheets, as for the measurement of Young's and Kirchhoff's moduli, assuming the determined values as data, was prepared. For the compressed package and adopted Young's modulus in a direction perpendicular to the sheet layers, FEM calculation results and calculation results according to Hooke's law in the linear range of the pre-compressed package 
were fully compatible. For the package loaded as during determination of Kirchhoff's modulus, i.e. loaded with pressure force of $1.48 \mathrm{MPa}$ and transverse force of $851 \mathrm{~N}$, the measured deflection of the roller middle layer was $u=0,016 \mathrm{~mm}$ (measurement error of approx. $\pm 0,001 \mathrm{~mm}$ ).

The FEM calculation results of the modelled roller - the package of sheets and loaded as during measurement is illustrated in Figure 9.
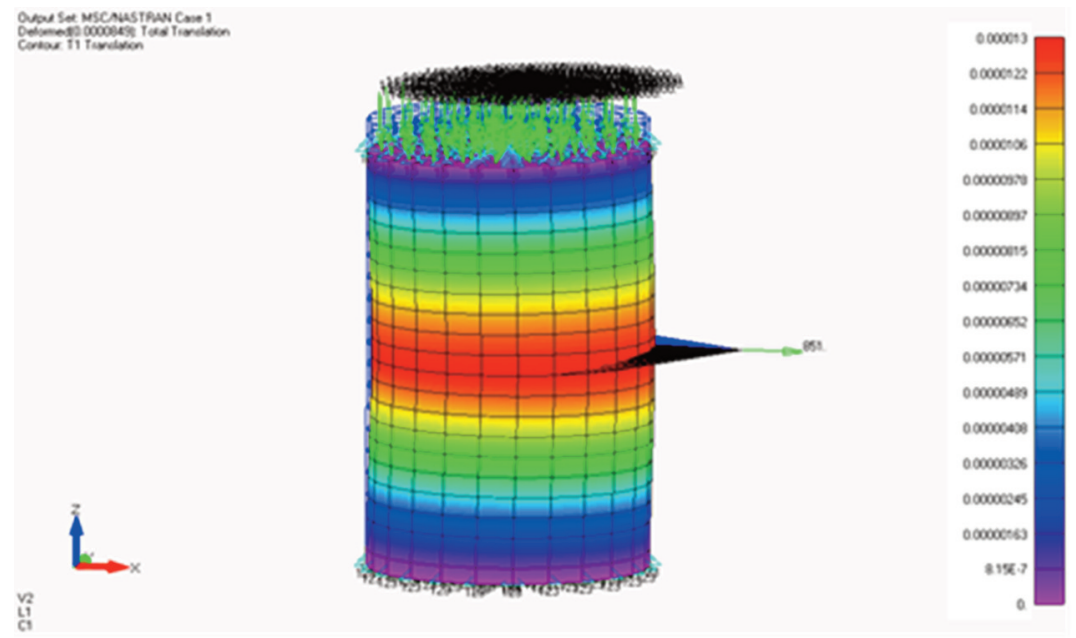

Fig. 9. FEM calculation results for the compressed and shorn package of sheets [Author, 2015]

For the calculations with the use of the NASTRAN programme, the 3D orthotropic material model was adopted. According to the calculations, the displacement of the central section of the package in the shear force direction should have $u=0.013 \mathrm{~mm}$, that is approx. $20 \%$ less than the measurement one. The reason for this discrepancy may be transverse flexibility of the measuring head of the testing machine that is difficult to measure.

\section{CONCLUSIONS}

On the basis of the conducted work, it is possible to formulate the following conclusions:

1. The carried out FEM comparative calculations confirmed correctness of the determined mechanical parameters of the package of sheets as a 3D orthotropic material, i.e. Young's modulus, Kirchhoff's modulus and Poisson's ratio, which are included in the linear range for the compressive stress range of $1.0 \div 2.5 \mathrm{MPa}$.

2. The determined mechanical properties of the package of sheets are necessary at the design stage for FEM simulation calculations of vibration properties of the electric motors with medium $(100 \div 700 \mathrm{~kW})$ and high power $(\geq 1 \mathrm{MW})$, especially, in case of modern rotors with supercritical rotations (motors rotating at the frequency higher than the frequency of the motor shaft bending).

3. In order to determine the properties of sheets from another manufacturer or coated with different insulating lacquer, the tests should be repeated. 


\section{BIBLIOGRAPHY}

[1] COGENT Surahammars Bruks AB. „Katalog wyrobów” [”Catalogue of goods”], 2009, Blacha SURA M400-50A.

[2] Idziak P., 2011, „Częstotliwości własne drgań wirnika silnika synchronicznego z magnesami trwałymi" ["Vibration natural frequencies of the synchronous motor's rotor with permanent magnets"], Zeszyty Problemowe Maszyny Elektryczne [Electrical Machines - Transactions Journal] (92), pp. $157 \div 161$.

[3] Podhajecki J., Szymaniec S., 2010, „Wyznaczanie drgań własnych wirnika silnika indukcyjnego" ["Determination of self vibration of the induction motor's rotor"], Zeszyty Problemowe Maszyny Elektryczne [Electrical Machines - Transactions Journal], (87), pp. $173 \div 177$.

[4] Kukula P., Ondrušek C., 2007, "Electric machine vibration analysis", Konferencja Prac Dyplomowych [Conference of Diplomas], Brno.

[5] Malicki M., 2015, „Badania grubości powłoki blachy elektrotechnicznej” [”Tests of thickness of the electrical sheet's layer"], Warsaw, Institute of Aviation, unpublished.

\section{WŁAŚCIWOŚCI MECHANICZNE PAKIETU BLACH FERROMAGNETYCZNYCH}

\section{Streszczenie}

W artykule przedstawiono metodę i wyniki pomiarów oraz wyniki obliczeń porównawczych mających na celu wyznaczenie danych materiałowych dla pakietu blach ferromagnetycznych izolowanych lakierem epoksydowym. W badaniach pakiet blach został potraktowany jako materiał ortotropowy 3D. Wyznaczono wartości modułów Younga i Kirchhoffa dla wstępnie ściśniętego pakietu blach, zgodnie ze stosowaną technologią wykonania wirników silników elektrycznych średniej i dużej mocy. Przeprowadzone obliczenia porównawcze MES potwierdziły, że wyznaczone parametry mechaniczne pakietu blach jako materiału ortotropowego 3D, tj. moduł Younga i moduł Kirchhoffa, dla przedziału naprężeń ściskających 1,0 $\div 2,5 \mathrm{MPa}$ są w zakresie liniowym. Oceniono, że wyznaczone właściwości mechaniczne pakietu blach są niezbędne na etapie projektowania do obliczeń symulacyjnych MES właściwości drganiowych i wytrzymałościowych silników elektrycznych. W wyniku badań stwierdzono, że badania należy powtórzyć w celu wyznaczenia właściwości innych blach lub pokrytych innym lakierem izolującym.

Słowa kluczowe: silnik asynchroniczny, pakiet blach, MES, drgania. 